УДК 349.2

DOI https://doi.org/10.32849/2663-5313/2019.6.19

\title{
Марія Світенок,
}

старший викладач кафедри філософії і суспільних наук

Чернігівського начіонального технологічного університету

\section{ПОСАДОВА ІНСТРУКЦІЯ: ПОНЯТТЯ ТА ПРАВОВА ПРИРОДА}

Стаття присвячена проблемам правового регулювання посадової інструкції. Автор наголошує, що трудове законодавство України не містить ні визначення посадової інструкції, ні вимог щодо ї̈ складання, змісту, порядку прийняття та внесення змін, проиедури скасування. Запропоновано врегулювати питання посадових інструкиій працівників у новому Трудовому кодексі України.

Ключові слова: посадова інструкція, правове регулювання, працівник, роботодавець.

Постановка проблеми. В умовах триваючого реформування трудового законодавства України одним із важливих кроків є необхідність прийняття нового Трудового кодексу, який би підняв рівень регулювання трудових відносин на більш високий рівень. У цьому аспекті важливими є врегулювання питань ефективної організації праці на всіх підприємствах, в установах і організаціях. Організацію праці можна розглядати як сукупність різних відносин: організаційних, економічних, правових, етичних, технічних, технологічних тощо. Працівник бере участь у всіх видах відносин, а його правове положення визначається різними документами, зокрема й посадовими інструкціями. У процесі реформування трудових відносин в Україні однією з невирішених проблем належної організації праці є проблема правового регулювання посадових інструкцій працівників підприємств, установ і організацій.

Аналіз останніх досліджень та публікацій. На жаль, дослідники не часто звертають увагу на цю проблему. Проте питання щодо посадових інструкцій працівників були предметом дослідження таких авторів, як: І. Биць, О. Виноградова, Ф. Кадиров, Л. Кулбужева, Л. Нечаюк, А. Петерс, О. Ткачівська, О. Хованська, Х. Юдіна, А. Юшко тощо.

Метою цієї статті є дослідження теоретичних та практичних проблем правового регулювання посадових інструкцій працівників підприємств, установ і організацій за трудовим законодавством України.

Виклад основного матеріалу. Для ефективної організації праці на всіх підприємствах, в установах і організаціях розробляють посадові інструкції, які є документом, в якому визначаються основні функції, права та обов'язки найманих працівників. Більше того, посадова інструкція є інструментом організації праці в її правовій формі, дає чітке уявлення про трудові обов'язки працівника і допомагає вирішувати трудові спори, що виникають.

Посадова інструкція - це один із локальних нормативних актів, що приймається роботодавцем. Норми, закріплені в посадовій інструкції, не мають погіршувати становище працівників порівняно зі встановленим трудовим законодавством та іншими нормативними правовими актами, що містять норми трудового права, колективним договором, угодами.

Таким чином, посадові інструкції мають відповідати чинному трудовому законодавству і є правовою основою для застосування до працівників заходів впливу. Згідно 3 п. 1 ст. 29 Кодексу законів про працю України (далі - КЗпП України), до початку роботи за трудовим договором власник або уповноважений ним орган зобов'язаний роз'яснити працівникові його права й обов'язки. Якщо права працівників є переважно загальними, вони визначаються в колективному договоpi, у правилах внутрішнього трудового розпорядку, то обов'язки кожного працівника залежать від посади, яку він обіймає (виконуваної ним роботи), і закріплені саме в його посадовій інструкції. На підставі вищевикладеного можна зробити висновок, що на всіх підприємствах незалежно від форм власності мають бути розроблені й затверджені посадові інструкції, адже саме вони сприяють чіткій організації виробництва і визначають конкретні завдання, функції, права й обов'язки працівників підприємства. Відсутність же посадових інструкцій на посади, що передбачаються в штатному розкладі, треба вважати порушенням вимог законодавства про працю, за яке власник або уповноважений ним орган може нести відповідальність згідно із законодавством [1, с. 6]. 
Вимоги посадової інструкції обов'язкові для найманого працівника 3 моменту ознайомлення з нею під розпис і до переведення на іншу посаду або припинення трудових відносин.

Якщо посадова інструкція не розроблена або якщо працівника не ознайомлено з їі змістом під розпис, притягнути його до відповідальності за, наприклад, невиконання або неналежне виконання трудових обов'язків буде досить проблематично. Ми погоджуємось із думкою О. Ткачівської, що відсутність посадової інструкції може викликати труднощі для роботодавця щодо звільнення працівника за п. 2 ст. 40 КЗпП України в разі «виявлення невідповідності працівника займаній посаді або виконуваній роботі внаслідок недостатньої кваліфікації або стану здоров'я». Це саме стосується і випадку звільнення за цією ж підставою у разі «скасування допуску до державної таємниці, якщо виконання покладених на нього обов'язків вимагає доступу до державної таємниці». Саме положення посадової інструкції можуть бути аргументом у спорі між роботодавцем та працівником, прийнятим із випробувальним терміном, під час звільнення з посади з причини непроходження випробування (ст. 28 КЗпП України) [2].

Нині чинне законодавство України використовує термін «посадова інструкція». Так, Довідник кваліфікаційних характеристик професій працівників, затверджений Наказом Міністерства праці та соціальної політики України від 29 грудня 2004 року № 336 (далі - Довідник) [3], - це загальний довідник, який застосовується для всіх видів економічної діяльності. Але $є$ й галузеві довідники, призначені для працівників окремих галузей господарства. Нині їх налічується вже понад 90 [4, с. 92].

Довідник служить основою розроблення посадових інструкцій, які закріплюють обов'язки, права та відповідальність. Пункт 6 Довідника закріплює, що конкретний перелік посадових обов'язків визначається посадовими інструкціями керівників, професіоналів, фахівців, технічних службовців, які розробляють і затверджують на основі Довідника роботодавці, враховуючи конкретні завдання та обов'язки, функції, права, відповідальність працівників цих груп та особливості штатного розпису підприємства, установи, організації. Під час розроблення посадових інструкцій забезпечується єдиний підхід до побудови, структури і викладу змісту розділів. Інструкції мають відображати повний перелік завдань та обов'язків, повноважень і відповідальності, у разі потреби мати необхідні пояснення, а всі термі- ни - чіткі визначення. Якщо виникає необхідність, завдання та обов'язки, що включені до типової кваліфікаційної характеристики тієї або іншої посади, можуть бути розподілені між окремими виконавцями або коло завдань та обов'язків окремих працівників може бути розширене з дорученням їм робіт, передбачених для різних груп посад, рівних за складністю, виконання яких не потребуе іншої спеціальності, кваліфікації. Усі посадові інструкції, що розробляються на підприємствах, в установах, організаціях, мають бути взаємопов'язаними, аби не допускати дублювання в роботі працівників. Посадові інструкції після їх затвердження керівником підприємства, організації, установи або за дорученням його заступниками доводяться до працівника під розписку. До посадових інструкцій може бути внесено зміни, доповнення лише на підставі наказу керівника підприємства, установи, організації за згодою працівника. Наказ про внесення змін, доповнень до посадової інструкції видається в разі перерозподілу обов'язків між працівниками у зв’язку зі скороченням чисельності, раціональним розподілом праці. У разі зміни назви підприємства, установи, організації, їхнього структурного підрозділу або посади до посадових інструкцій вносяться відповідні зміни. Посадові інструкції складаються для працівників усіх посад, що зазначені в штатному розписі [3].

Правове регулювання посадової інструкції знаходимо також у підрозділі 6 розділу II Правил організації діловодства та архівного зберігання документів у державних органах, органах місцевого самоврядування, на підприємствах, в установах і організаціях. У цьому документі зазначено, що затвердження управлінських документів здійснюється особисто посадовою особою (посадовими особами) відповідно до їі (їхніх) повноважень або розпорядчим документом установи із зазначенням на документі грифа затвердження, оформленого відповідним чином. Розпорядчим документом установи затверджуються положення про структурні підрозділи, інструкції, правила, порядки та інші документи нормативно-правового або нормативного характеру. Посадовою особою особисто затверджуються документи, що не потребують додаткових вказівок, завдань щодо їх упровадження або виконання (положення (статути) установи, протоколи, акти, плани, звіти, кошториси, штатні розписи, посадові інструкції, програми, нормативи тощо) [5].

Отже, розробці посадових інструкцій передує вивчення всіх нормативно-правових документів, що регламентують порядок діяльності посадових осіб та правила роз- 
робки і зберігання цих організаційно-правових документів. Сам же процес розроблення посадових інструкцій можна представити у вигляді таких етапів: 1) підготовчий етап; 2) розробка проекту посадової інструкції; 3) узгодження проекту посадової інструкції; 4) затвердження посадової інструкції.

Варто звернути увагу також на те, що Міністерство праці та соціальної політики України свого часув Листі від 03.10.2005 року № 36-508 «Щодо посадових інструкцій працівників» повідомило, що конкретний перелік посадових обов'язків визначається посадовими інструкціями керівників, професіоналів, фахівців, технічних службовців, які розробляють і затверджують на основі Довідника кваліфікаційних характеристик професій працівників, затвердженого наказом Міністерства праці та соціальної політики України від 29.12.2004 р. № 336, роботодавці, враховуючи конкретні завдання та обов'язки, функції, права, відповідальність працівників цих груп та особливості штатного розпису підприємства, установи, організації. Посадові інструкції, після їх затвердження керівником підприємства, організації, установи або за дорученням його заступниками, обов'язково доводяться до працівника під розписку. Посадові інструкції складаються для працівників усіх посад, що зазначені в штатному розписі. Виняток можуть становити окремі керівники, правове становище яких визначено в Статуті (Положенні) підприємства, установи, організації або відповідного підрозділу, де зазначені основні завдання, обов'язки, права і відповідальність за виконання покладених на них функцій. Враховуючи вищезазначене, на основі кваліфікаційних характеристик посад працівників та особливостей штатного розпису керівник підприємства забезпечує розроблення та затверджує посадові інструкції працівників і доводить їх до працівників під розписку [6]. Також у цьому листі Міністерство погодилось із висновком про те, що роботодавець під час прийняття на роботу працівника роз'яснює його права та обов'язки, посилаючись на посадову інструкцію.

Варто зазначити, що нині в трудовому законодавстві України не встановлено легального визначення поняття посадової інструкції. Однак у ст. 4 КЗпП України встановлено, що до системи актів трудового законодавства відноситься Кодекс законів про працю України та інші акти законодавства України, прийняті відповідно до нього. Саме це твердження визначає можливість прийняття уповноваженими суб'єктами посадових інструкцій.
Проект Трудового кодексу України (далі - Проект) у п. 3 ст. 10 передбачає, що у випадках, передбачених законодавством, колективними угодами та колективними договорами, трудові відносини можуть регулюватися нормативними актами роботодавця. А п. 4 ст. 12 Проекту закріпив обов'язок роботодавця доводити прийняті нормативні акти до відома всіх працівників. Якщо нормативний акт стосується конкретного робочого місця чи конкретної посади (посадова інструкція, інструкція про порядок виконання робіт тощо), працівник знайомиться з ним під розписку у триденний строк [7].

Необхідність правового регулювання посадових інструкцій зумовлюється ще й тим, що, як правильно зазначає I. Биць, не треба недооцінювати значення посадових інструкцій, оскільки вони:

- установлюють та закріплюють конкретні завдання й обов'язки працівників, їхні права, відповідальність;

- $є$ нормативним підгрунтям для застосування до працівника заходів впливу;

- інформують працівника про його дії, яких від нього очікують; критерії оцінювання результатів його праці; орієнтири щодо підвищення рівня кваліфікації в межах конкретної професії $[1$, с. 6].

Відсутність же законодавчого визначення цієї категорії зумовила існування великої кількості підходів до визначення етимології поняття посадової інструкції.

Посадова інструкція - документ, що визначає організаційно-правове становище у структурному підрозділі, що забезпечує умови для його ефективної праці. Посадові інструкції встановлюють права та обов'язки працівників, їх підпорядкування, назву та специфіку посади, кваліфікаційні вимоги, відповідальність працівника, затвердження інструкції та інше [8].

Посадова інструкція - інструкція, яка вказує коло доручень, обов'язків, робіт, які має виконати особа, що обіймає цю посаду на підприємстві [9]. Однак, крім обов'язків, посадова інструкція має чітко визначати права робітника, вимоги до його кваліфікації, знань і навичок, підпорядкованість і умови праці. Відповідно до цього в ретельному та якісному складанні посадової інструкції зацікавлений сам працівник [10, с. 185].

Посадова інструкція - документ, який включає в себе конкретизовані трудові функції, навички тощо на основі професійних стандартів (за їх наявності) або кваліфікаційних довідників [11, с. 71].

Посадова інструкція є, з одного боку, організаційно-розпорядчим документом, який визначає посадові обов'язки кожного 
працівника, його права й відповідальність за виконувану роботу, з іншого - нормативною основою для оцінки діяльності працівника, встановлення його відповідності посаді, яку він обіймає [12, с. 279-280]. Ми погоджуємось 3 думкою А.Н. Петерса, що посадова інструкція містить обсяг прав і обов'язків працівника, тобто індивідуалізує посаду [13, c. 23].

Варто також погодитись 3 тим, що посадові інструкції дають можливість: раціонально розподіляти функціональні обов'язки між працівниками; підвищити своєчасність і надійність виконання завдань; покращити соціально-психологічний клімат у колективі; чітко визначити функціональні зв'язки робітника; конкретизувати права працівника; підвищити колективну й особисту відповідальність; підвищити ефективність морального й матеріального стимулювання; організувати рівномірне завантаження працівників [14, с. 85-86].

Таким чином, з огляду на вищевикладене, можна виділити такі основні положення, що стосуються посадових інструкцій:

1) у трудовому законодавстві України відсутні норми, які чітко визначають порядок складання, оформлення і внесення змін до посадової інструкції. Роботодавець має право самостійно приймати рішення про те, яким чином оформити посадову інструкцію та її зміст;

2) роботодавець має право в процесі трудової діяльності уточнити посадові обов'язки працівника, деталізувавши їх до конкретних дій, що дасть змогу у разі притягнення працівника до дисциплінарної відповідальності вказати пункт посадової інструкції, який порушений працівником;

3) відмова працівника від підпису про ознайомлення з внесенням змін до посадової інструкції або з новою посадовою інструкцією не є підставою для звільнення працівника за п. 6 ст. 36 КЗпП України (відмова від продовження роботи у зв'язку зі зміною істотних умов праці);

4) посадові обов'язки працівника мають бути вказані максимально чітко, не містити розмитих формулювань і не допускати декількох варіантів тлумачення;

5) посадова інструкція має усувати невизначеність у наповненні функціональних обов'язків працівника.

\section{Висновки}

Посадова інструкція $є$ інструментом організації праці в іїі правовій формі, оскільки посадова інструкція дає змогу створити ефективну організацію трудових відносин і зачіпає інтереси всіх працюючих і робото- давців. Пропонуємо в новому Трудовому кодексі України закріпити положення про те, що під посадовою інструкцією слід розуміти локальний нормативно-правовий акт, що містить завдання, трудову функцію та конкретний перелік посадових обов'язків працівника 3 урахуванням особливостей організації виробництва і праці, прав і меж його відповідальності, а також кваліфікаційні вимоги, що висуваються до обійманої посади. Було б доцільно також ввести в Трудовий кодекс України норми, що регулювали б складання, зміст, прийняття, зміну та скасування посадових інструкцій.

\section{Список використаних джерел:}

1. Биць I. Посадові інструкції: розроблення та оформлення. Праия і зарплата. 2017. № 23 (1035). 21 червня 2017. С. $6-7$.

2. Ткачівська О. Чи потрібні посадові інструкції для працівників? URL: http://dspif.gov.ua/ news/135-chi-potrbn-posadov-nstrukcyi-dlyapracvnikv.html.

3. Про затвердження Довідника кваліфікаційних характеристик професій працівників : Наказ Міністерства праці та соціальної політики України від 29 грудня 2004 року № 336. URL: http://search.ligazakon.ua/1_doc2.nsf/ link1/FIN16994.html.

4. Юшко А.М. Правове регулювання професійних стандартів в Україні. Право та інновачійне суспільство. 2018. № 2 (11). С. 89-96.

5. Про затвердження Правил організації діловодства та архівного зберігання документів у державних органах, органах місцевого самоврядування, на підприємствах, в установах і організаціях : Наказ Міністерства юстиції України від 18 червня 2015 року № 1000/5. URL: https://zakon.rada.gov. ua/laws/show/z0736-15.

6. Лист Міністерства праці та соціальної політики України «Щодо посадових інструкцій працівників» від 3 жовтня 2005 року № 36-508. URL https://zakon.rada.gov.ua/rada/show/v36-5203-05.

7. Проект Трудового кодексу України від 20 травня 2015 року (доопрацьований реєстр. № 1658). URL: http://w1.c1.rada.gov.ua/pls/ zweb2/webproc4 1?pf3511=53221.

8. Посадова інструкція. Вікіпедія: вільна енииклопедія. URL: https://uk.wikipedia.org/wiki/ Посадова_інструкція.

9. Хованская О. Должностные инструкции педагогов и тьюторов. Кадровик. Кадровое делопроизводство. 2012. № 2. URL: https://hr-portal.ru/article/dolzhnostnyeinstrukcii-pedagogov-i-tyutorov.

10. Виноградова О.М. Посадова інструкція аудитора як інструмент професійної діяльності. Науковий вісник Полтавського університету економіки і торгівлі. 2013. № 4 (60). С. 108-185.

11. Кадыров Ф.Н., Кулбужева Л.Ю. Должностная инструкция в условиях последних новаций в сфере трудових компетенций медицин- 
ских работников. Менеджер здравоохранения. 2016. № 5. C. 70-77.

12. Нечаюк Л.І., Телеш Н.О. Готельно-ресторанний бізнес: менеджмент : навчальний посібник. Київ : Центр навчальної літератури, 2003. 348 с.

13. Петерс А.Н. Должностная инструкция как средство индивидуализации трудовой функции работника. Вестник Омского юридического инстиmyта. 2011. № 3 (16). С. 2-25.

14. Юдіна Х.К. Методичний підхід до розробки посадових інструкцій управлінців готелю. Вісник Запорізького начіонального університету. Серія «Економічні науки». 2011. № 1(9). C. 84-89.

Статья посвящена проблемам правового регулирования должностной инструкиии. Автор отмечает, что трудовое законодательство Украины не содержит ни определения должностной инструкиии, ни требований по ее составлению, содержанию, порядку принятия и внесения изменений, проиедуры отмены. Предложено урегулировать вопрос должностных инструкиий работников в новом Трудовом кодексе Украины.

Ключевые слова: должностная инструкция, правовое регулирование, работник, работодатель.

The article is devoted to the problems of legal regulation of the job description. The author stresses that the labor legislation of Ukraine does not contain any definition of a job description, nor requirements for its compilation, content, procedure for acceptance and amendment, the procedure of cancellation. It is proposed to regulate issues of job descriptions of employees in the new Labor Code of Ukraine.

Key words: job description, legal regulation, employee, employer. 